\title{
THE POSSIBLE INVOLVEMENT OF D-AMINO ACIDS OR THEIR METABOLITES IN ARABIDOPSIS CYSTEINE PROTEINASE/CYSTATIN-DEPENDENT PROTEOLYTIC PATHWAY
}

\author{
A. GHOLIZADEH \\ Research Institute for Fundamental Sciences (RIFS), University of Tabriz, Iran \\ E-mail: aghz_bioch@yahoo.co.in
}

Cysteine proteinases and their inhibitors 'cystatins' play essential roles in plant growth and development. They are involved in various signaling pathways and in the response to wide ranges of biotic and abiotic environmental stresses. To investigate their possible influence from D-amino acids or their metabolism in vivo, Arabidopsis seedlings were allowed to grow under four physico-chemically different $D$-amino acids including $D$-aspartate, $D$-serine, $D$-alanine and D-phenylalanine containing media. The reverse transcription polymerase chain reaction ( $R T-P C R)$ analysis of cysteine proteinase and cystatin gene expressions showed that the addition of D-amino acid to the plant growth media considerably induce the expression of proteinase transcript while decrease the expression level of inhibitor gene in the leaf and root tissues of the test plant in overall. Based on the obtained results the potential impact of D-amino acids or their metabolism on the activity of cysteine proteinase/ cystatin-dependent proteolytic apparatus as well as their possible cooperation were predicted and discussed in the plant system.

Key words: Arabidopsis, cystatin, cysteine proteinase, $D$-amino acid, $R T$-PCR.

Introduction. In plants, proteolysis is a complicated process in which many enzymes and proteolytic pathways are involved. Cysteine proteinases (CP) referred to as thiol proteases are known to play an essential role and share in total proteolysis from 30 to $90 \%$ depending on the cellular conditions [1, 2]. CP enzymes are involved in protein maturation, degradation, protein rebuilt in response to different internal and external stimuli, continuous removal of protein abnormalities and mis-foldings during plants growth and developmental stages [3, 4]. In

(C) A. GHOLIZADEH, 2015 each case, the hyperactivity of CP enzymes leads to severe cellular disturbance. Therefore, proteolysis process is highly regulated. Cells or whole organisms have developed various strategies to protect themselves against undesired proteolysis. One of the common strategies is the control of proteolytic activity by inhibition [5]. It has been suggested that the CP-based proteolysis is regulated by the activity poised between the cysteine proteinases and their proteineous inhibitors referred as cystatins [6]. Recently, it has been reported that the cysteine proteinase and cystatin interactions determines their mutual participation in specific pathways including anabolic and catabolic processes, different signaling pathways and responding to various biotic and abiotic environmental stresses throughout the plants life [7].

Cystatins constitutes the largest and well characterized group of natural $\mathrm{CP}$ inhibitors (CPI) in plant system [8-10]. These proteineous inhibitors have been known to bind adjacent to the protease active site, obstructing the access of substrate, but they do not directly interact with the enzyme catalytic centre [15]. Cystatins mostly direct their inhibitory actions against the papain superfamily members found in a wide range of organisms including viruses, bacteria, plants and animals [5, 12]. The plant cystatins differ from microorganisms or animal types. They are generally named as «phytocystatins». Like all members of the cystatin super-family, phytocystatins contain three conserved regions ( $« \mathrm{G} »$ residue at the $\mathrm{N}$-terminus, $\ll Q \times V \times G »$ and $« W »$ at the $C$-terminus) that interact with cysteine proteinase molecular structures, but they differ from non-plant types due to the presence 
of a plant-specific sequence, [LVI]-[AGT]-[RKE][FY]-[AS]-[VI]-X-[EDQV]-[HYFQ]-N located in an $\mathrm{N}$-terminal $\alpha$-helix region $[13,14]$.

A survey of cystatins and cysteine proteinases in plants has suggested the conservation and evolution of the cystatin inhibitory family and their putative targets, the papain-type cysteine proteinases from families C1A and C13. Functionality of both families of proteins in plants was predicted to be the result of a coevolutionary process that might have occurred during the evolution of basal and land plants leading to a complex functional relationship among them [7, 15].

Plant papain-type proteinases are the most abundant and widely investigated family of cysteine proteases. These proteases are synthesized as inactive precursors and then their activation take place by limited intra or intermolecular proteolysis [16]. Genome annotation and sequence similarity search data has revealed that Arabidopsis encodes 32 papain-type ( $\mathrm{C} 1$ family) cysteine proteinases which are classified into eight main groups consisting of senescence and stress induced, aleurain, cathepsin-b like, bromelain-like, KEDL, telosequences and actinidain-like proteinases [2, 17]. This papain-type CP family was recently found to be important player in Arabidopsis immunity against pathogen infections [18].

Although the full physio-biological functions of plant cysteine proteinases and cystatins remain obscure, but studies on their gene expression patterns have been suggested that they may play important roles in plant system such as the regulation of seed maturation and germination, participation in the defense mechanism against pathogen attacks or against different abiotic environmental stresses such as drought, salt and heat and modulating the phenomenon of programmed cell death (PCD) during plant development and senescence [6, 19-21].

We predicted that the proteolytic pathway enzymes may be naturally influenced from the other metabolic pathways such as D-amino acid metabolizing rout in plants. Similar to proteolytic enzymes, D-amino acids and their metabolic enzymes have been known to be involved in a number of biological processes such as aging and tissue/organ growth and developments in mammalians [22, 23]. Using gene expression data, the possible contribution of D-amino acids and their related enzymes in some biological processes and in response to a number of environmental stresses such as drought have also been later on suggested in plant systems [23]. Although, the recent reports have demonstrated that the engineered D-amino acids and their synthetic derivatives affect the CP/CPI-dependent proteolytic activities $[24,25]$, but, there is no any information to our knowledge about the possible natural correlations that may be present between the proteolytic and D-amino acid metabolic routs, still yet.

In the present study, as an initial research work, our attempts were made to: 1) sketch in the basic and the quantitative RT-PCR based expression profiles of Arabidopsis papain-like proteinase (Accession no. At3G54940) and a cystain type inhibitor (Accession no. AF411786) in two different organs including leaves and roots, simultaneously; 2) study on the RT-PCR based expression profiles of papain-like and cystatin genes in the presence of D-amino acid containing media that may help us to understand about the possible functional relationships between D-amino acid metabolism and CP/CPI based proteolytic pathway in plant system.

Materials and methods. Bacterial strains and chemicals. E. coli strain DH5 $\alpha$ was used for the bacterial transformation. pGEM-T Easy vector system I from Promega (Cat. No. A1360) was used for the PCR product cloning. Trizol reagent used for total RNA isolation was purchased from Gibco BRL, USA (Cat. No. 15596-013). The mRNA mini preparation kit was from QIAGEN, USA (Cat. No.70022). AcessQuick ${ }^{\mathrm{TM}}$ RT-PCR System was purchased from Promega (Cat. no. A1701). iQ SYBR green supermix was from Bio-Rad, USA. Restriction enzymes, Taq DNA polymerase, buffer, dNTPs, and $\mathrm{MgCl}_{2}$ used for PCR amplification were provided by CinnaGen Company. In order to purify the PCR end product from the agarose gel materials, Fermentas DNA extraction kit (Cat. No. K0513) was used. All the other chemicals were of analytical and molecular biology grades and purchased from Merck AG (Darmstadt, Germany) or Sigma (St. Louis, MO, USA).

Plant materials and growth conditions. The seeds of Arabidopsis thaliana (thale cress) were provided by Dr B. Baghban Kohnehrouz (Laboratory of Plant Genetic Engineering, Department of Plant Breeding and Biotechnology, University of Tabriz, Iran). The seeds were germinated up to seedling stages, and then each seedling separately transferred 
to the nitrate-free Hoagland solution containing $1000 \mathrm{ppm}(1 \mathrm{~g} / \mathrm{L}) \mathrm{D}$-amino acid as nitrogen source. Four different amino acids including D-aspatate, $\mathrm{D}$-serine, D-alanine and D-phenylalanine were considered for the analysis. Each medium included only one type of amino acid. The experimental materials were collected from the fresh leaf and root tissues after one week and proceeded for the simultaneous RNA isolation and RT-PCR reactions.

Total RNA isolation and $m R N A$ purification. Total cellular RNA was isolated from the leaf and root materials using Trizol reagent, separately. $0.2 \mathrm{~g}$ of each test material was powdered using liquid $\mathrm{N}_{2}$ and $2 \mathrm{ml}$ of Trizol reagent was added to homogenize it at room temperature (RT). Then, $200 \mu$ of chloroform was added to the mixture, mixed for 15 second, incubated on ice for $5 \mathrm{~min}$ and centrifuged at $13000 \mathrm{~g}$ for $15 \mathrm{~min}$. The upper phase was transferred to another tube and RNA was precipitated with an equal volume of isopropanol. The pellet was washed in $1 \mathrm{ml}$ of $75 \%$ ethanol, dried at RT and dissolved in $30 \mu \mathrm{l}$ RNase-free water. The integrity of the RNA was tested on $1 \%$ non-denaturing agarose gel using TBE running buffer. Poly $\left(\mathrm{A}^{+}\right) \mathrm{RNA}$ was purified from prepared total RNA using oligo dT-columns according to the provided kit protocol. The integrity of the purified mRNA was also analyzed by electrophoresis using $1 \%$ non-denaturing agarose gel. The quantity of the RNA in the starting materials for the next experiments was measured spectrophotometrically [26].

Primer Designing. The specific primer sets for the amplification of Arabidopsis papain-like cysteine proteinase and a cystatin cDNA were designed based on their already reported sequences (The EMBL accession numbers for papain-like and cystatin sequences were At3G54940 and AF411786, respectively). The sequence-specific primers for $\mathrm{CP}$ (Fw, 5'CGATAACAGCGATCATGGTG3'; Rv, 5'GAAACTTGGGTGGCTACTGC3') and CPI (Fw, 5'GAAAATGGCGGATCAACAAG3'; Rv, 5'ACATCGTGATGGTGGTTGAA3') were designed by Primer3 software (http://www. Primer3plus.com).

RT-PCR Reactions. The RT-PCR reactions were separately performed for each test samples using one-step AcessQuick ${ }^{\mathrm{TM}}$ RT-PCR System. $0.5 \mu \mathrm{g}$ of each mRNA sample was mixed with $25 \mu$ l Master Mix $(2 x)$ and $1 \mu \mathrm{l}$ of primer set (at the final concentration of $0.2 \mu \mathrm{M}$ ). The mixtures were adjusted to a final volume of $50 \mu \mathrm{l}$ using nuclease-free water. The reaction mixtures were incubated at $45^{\circ} \mathrm{C}$ for $45 \mathrm{~min}$, the subsequent PCR amplification was carried out after a pre-denaturation stage at $95^{\circ} \mathrm{C}$ for 3 minutes in 25 cycles. The PCR cycles for $\mathrm{CP}$ and CPI amplifications were performed according to the following programs, respectively: «denaturation at $93{ }^{\circ} \mathrm{C}$ for $30 \mathrm{~s}$, annealing at $55{ }^{\circ} \mathrm{C}$ for $2 \mathrm{~min}$, extension at $72^{\circ} \mathrm{C}$ for $1 \mathrm{~min}$, final extension at $72{ }^{\circ} \mathrm{C}$ for $10 \mathrm{~min}$ » and «denaturation at $93{ }^{\circ} \mathrm{C}$ for $1 \mathrm{~min}$, annealing at $56{ }^{\circ} \mathrm{C}$ for $1.5 \mathrm{~min}$, extension at $72{ }^{\circ} \mathrm{C}$ for $2 \mathrm{~min}$, final extension at $72{ }^{\circ} \mathrm{C}$ for $10 \mathrm{~min}$.

In the next step, the amplified products were extracted from the agarose gel, cloned in pGEM$\mathrm{T}$ easy cloning vector [37]. The cloned fragments proceeded for the partial sequencing in Microsynth DNA sequencing center at Switzerland.

Real-time RT-PCR reactions. The real-time RTPCR reactions were analyzed by using iQ SYBR green dye on Miniopticon Real Time PCR Detection System (Bio-Rad, USA). Each sample was performed in three replicates and the mean values of the data were presented. All the data were normalized by actin reference gene expression values in the test samples and the relative fold expression was calculated using the $2^{- \text {DDCt }}$ value [27].

Sequence Analysis. To ensure that the amplified products are corresponding to our sequences of interest, the nucleotide and deduced amino acid sequences of the isolated cDNA were analyzed by computing at BLAST (Basic Local Alignment Search Tool; http://www.ncbi.nlm.blast.com/).

Results and discussion. Using gene expression technologies, plant cysteine proteinases (CP) and their inhibitors (CPI) have been suggested to be contributed in many biological processes in a regulative manner. They are mostly involved in protein turnovers, programmed cell death and protein degradations in response to several internal developmental shifting and external stressful environments [4, 28]. Wounding, low or high temperatures, drought, high salinity and diseases have been reported to alter the expression patterns of CP and CPI genes [28, 29]. In senescing and developing plants as well as in germinating seeds, the $\mathrm{CP} / \mathrm{CPI}$ gene activities have been shown to be regulated $[19,21]$.

Besides the gene expression alterations, the bimolecular fluorescent complementation data analysis have newly demonstrated that the $\mathrm{CP}$ and CPI 


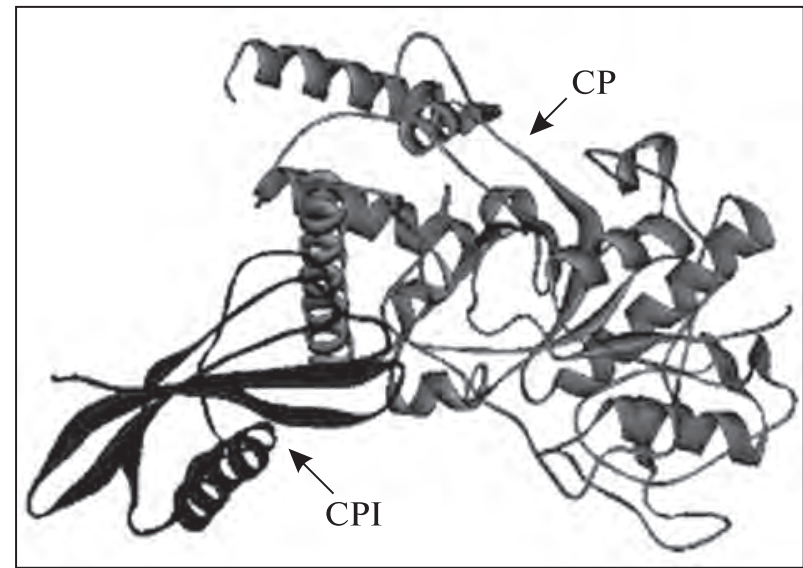

Fig. 1. Presentation of $\mathrm{CP} / \mathrm{CPI}$ interactive structure. The interaction between the test $\mathrm{CP}$ and CPI molecules were predicted by using computational molecular docking
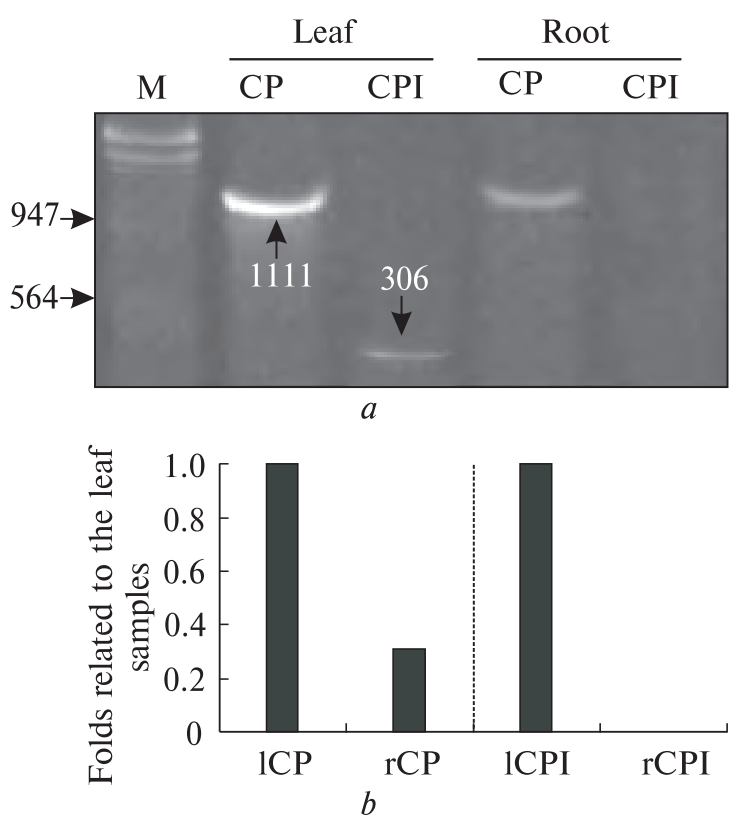

Fig. 2. Expression analysis of $\mathrm{CP} / \mathrm{CPI}$ genes in the leaf and root tissues: $a$ - the expression of papain-like proteinase and cystatin transcripts were detected by RTPCR reactions in the leaves and roots of Arabidopsis test plants grown in D-amino acid free Hoagland solutions. Electrophoresis was carried out using $1 \%$ non-denaturing agarose gel; $b$ - quantitative expression analysis of $\mathrm{Cp} /$ CPI genes was performed by real time RT-PCR using iQ SYBR Green dye. Data were normalized by actin and related to leave samples using $2^{-D D C t}$ value. Here and Fig. 3-6: 1CP - leaf CP; rCP - root CP; 1CPI - leaf CPI; rCPI - root CPI; M - EcoRI and HindIII double digested DNA markers; $\mathrm{CP}$ - cysteine proteinase; CPI cysteine proteinase inhibitor molecules are interacted in a regulated manner and participate in the same bio-physiological processes [7]. Also the relative activities poised by the proteinases and inhibitors have been suggested to determine their regulated function in vivo [6]. The relative enzymatic and inhibitory activities of $\mathrm{CP} / \mathrm{CPI}$ proteolytic pair have been recently reported to be influenced from several non-natural D-amino acid derivatives [24, 25]. These compounds are known to increase the inhibitory activity of inhibitor molecules and relatively decrease the protease activity in the treated cells or tissues.

In the present study, we aimed to investigate the possible effects of exogenously applied D-amino acids on the expression patterns of Arabodopsis papain-like proteinase and a cystatin, simultaneously. For this purpose, four structurally and physico-chemically different D-amino acids including D-aspartate, D-serine, D-alanine and Dphenylalanine were considered as nitrogen source for test plant seedlings. Seedlings were allowed to grow in nitrate-free Hoagland solutions containing 1000 ppm D-amino acids, separately. After one week, experimental materials were simultaneously collected from the leaf and root tissues of growing plants and subjected to the gene expression studies. The Cp/CPI pair was selected according to their computational predictable interactive structures (Fig. 1). Using molecular docking analysis data, the interaction energy between this pair was predicted to be $19559.2 \mathrm{kcal} / \mathrm{mol}$. This interactive structure was also found to be the most popular model between Arabidopsis papain-type Cp/CPI molecules.

The expression of CP and CPI transcripts were detected by RT-PCR and real-time RT-PCR methods using the same amounts of the starting mRNA materials for all of test samples. Analysis of the RT-PCR end products showed that the expression patterns of CP and CPI are considerably influenced from the D-amino acid containing growth media. In the medium without $\mathrm{D}$-amino acids, the expression of CP was detected in both leaf and root tissues, but CPI transcript was only observed in the leaf tissues. The results failed to show evidence of CPI gene expression in the root materials. Analysis of the $2^{- \text {DDCt }}$ values reliably revealed that there is about 3.2 fold increase in the expression level of leaf CP gene as compared to the root sample (Fig. 2).

The partial nucleotide sequences of the amplified $C P$ and $C P I$ fragments were analyzed by BLAST 
and their complete identity with the already reported sequences were confirmed by CLASTAW (the sequences and the alignment results not presented).

In D-aspartate containing medium, the expression patterns of CP and CPI were found to be the similar to the D-amino acid free media, while the relative levels of their expression were considerably different (Fig. 3). In compare to the samples of the D-amino acid free medium (considered as control), the expression levels of CP in D-aspartate plus medium were increased in both root and leaf tissues. The folds increase in the CP levels of leaf and root samples were found to be about 1.9 and 2.1 , respectively. In contrast, the CPI gene expression in the leaves of D-aspartate plus medium was decreased about $50 \%$ as compared to the samples collected from D-amino acid free medium.

In $\mathrm{D}$-serine containing medium, the patterns and the levels of the root CP and CPI expressions were found to be the same as for the samples collected from the D-amino acid free medium, while the expression of CP/CPI in the leaf samples were different. The leaf CP showed the same expression pattern, but no expression signal was detected for the CPI gene (Fig. 4).

Comparison of the $\mathrm{CP} / \mathrm{CPI}$ gene expressions in $\mathrm{D}$-alanine plus and $\mathrm{D}$-amino acid free media showed that root $\mathrm{CP}$ is increased to about 2 fold, but the leaf $\mathrm{CP}$ remained the same. Analysis of CPI expression level showed that leaf CPI gene expression is about $50 \%$ decreased, but the root CPI gene expression is not detectable as the same as control (Fig. 5).

In D-phenylalanine containing medium, the expression levels of leaf and root CP showed about 2.4 and 2.1 fold increases, respectively. Analysis of the expression of CPI gene revealed that its patterns and the levels remained as the same as the controls in both leaf and root tissues (Fig. 6).

In overall, analysis of the expression data related to the samples collected from the D-amino acid containing media indicated that the expression patterns of the CP and CPI genes are similar to the samples of D-amino acid free medium, but the levels of their expressions are differential.

This study for the first time reports the expression analysis of cysteine proteinase and its potent inhibitor in plant system, simultaneously. Previously, the expression patterns of CP or CPI have been individually investigated and suggested their potent effects on various developmental processes
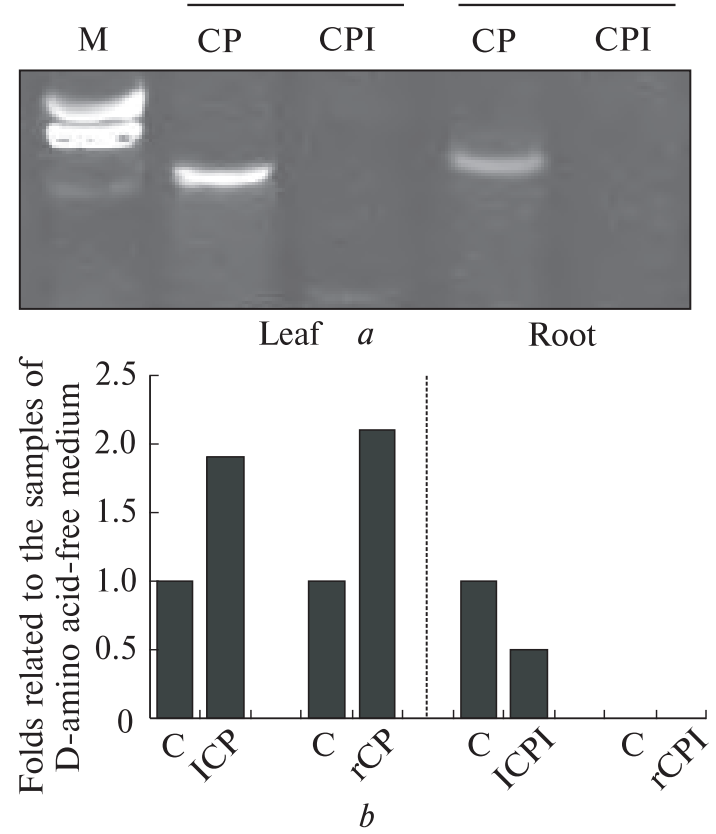

Fig. 3. Effects of D-aspartate on the expression of $\mathrm{CP} /$ CPI genes: $a-$ the expression of CP and CPI transcripts were analyzed by RT-PCR method from Arabidopsis test plants grown in Hoagland solutions containing 1000 ppm D-aspartate; here and Fig. 4-6 $b$ - the expression levels of $\mathrm{CP} / \mathrm{CPI}$ related to the $\mathrm{D}$-amino free media using $2^{-\mathrm{DDCt}}$ value in real-time PCR

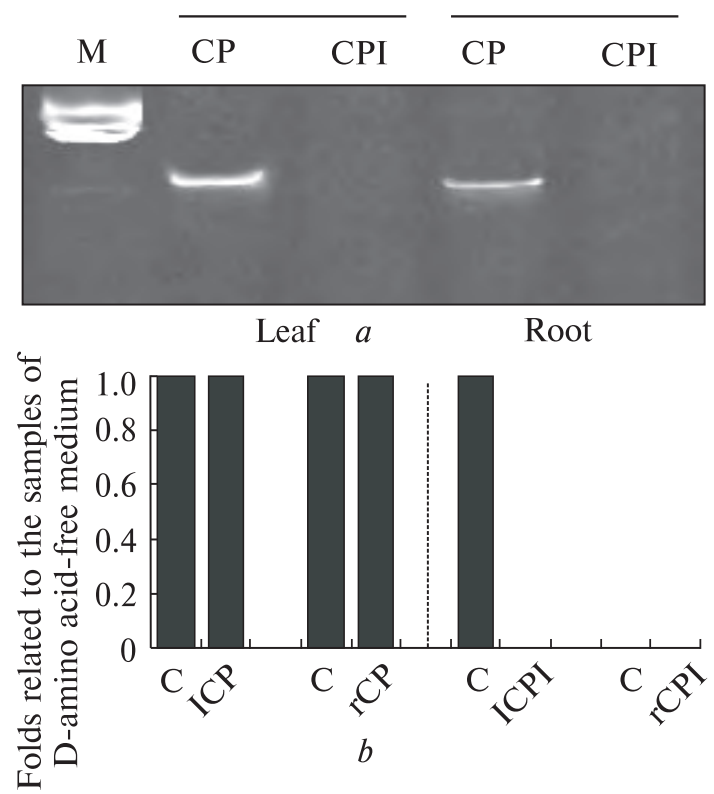

Fig. 4. Effects of D-serine on the expression of $\mathrm{CP} / \mathrm{CPI}$ genes: $a$-comparative expression analysis of $\mathrm{CP}$ and $\mathrm{CPI}$ genes were carried out by RT-PCR in the test plants grown in Hoagland solutions containing 1000 ppm D-serine 

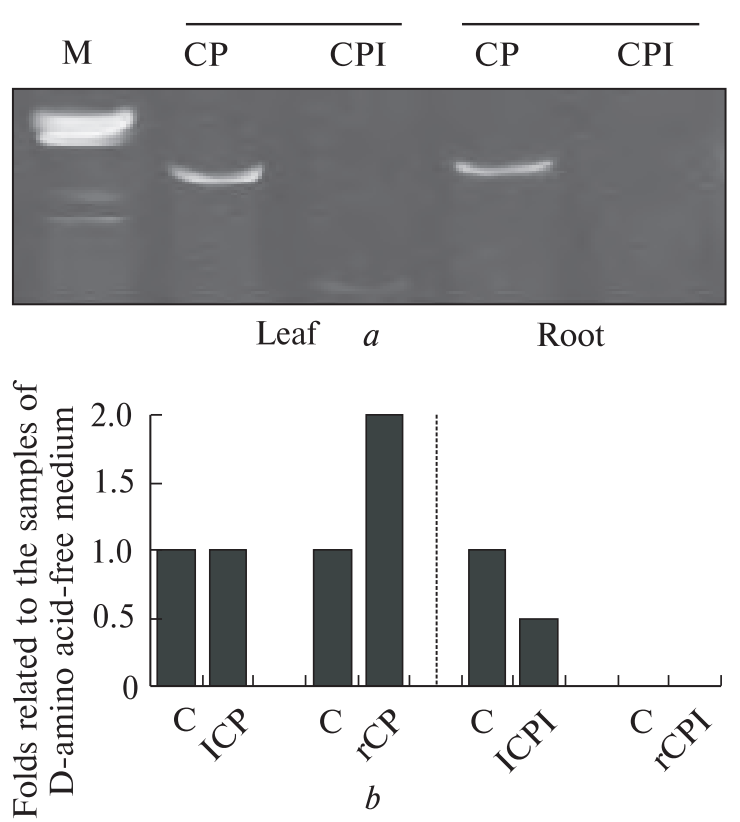

Fig. 5. Effects of D-alanine on the expression of $\mathrm{CP} /$ CPI genes: $a-$ RT-PCR based expression analysis of $\mathrm{CP}$ and CPI genes were carried out in test plants grown under D-alanine containing media
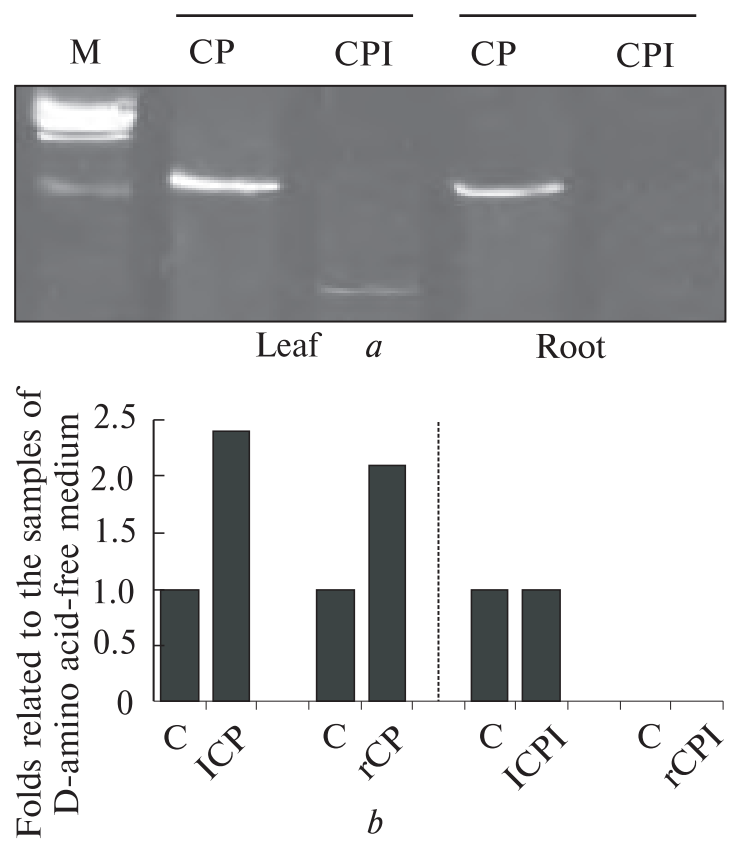

Fig. 6. Effects of D-phenylalanine on the expression of CP/CPI genes: $a$ - the expression patterns of $\mathrm{CP}$ and CPI genes were analyzed by RT-PCR method from plants grown in Hoagland solutions containing 1000 ppm D-phenylalanine as well as on different responses against stressful environmental stimuli $[4,18,28]$. However, our simultaneous studies firstly revealed that the expression pattern of CP is different from that of CPI in two different organs of test plants. Secondly, the overall obtained results indicated that $\mathrm{CP}$ gene is highly active than CPI gene in both organs. This may reflect the wide regulation of CPI inhibitory activity by the natural or non-natural compounds.

The various synthetic and non-natural derivatives of D-amino acids have been previously known to activate the inhibitory function of CPI [25]. An engineered CPI molecule with $\mathrm{D}$-amino acid residues has also been shown to get higher inhibitory activity towards human immunodeficiency virus (HIV) proteinase [24].

Our present studies on gene expression patterns confirmed that D-amino acids of plants growth media have different effects on gene activities and the expression levels of CP and CPI. In overall, our data revealed that D-amino acids of the growth media could able to increase the $\mathrm{CP}$ expression level, while decrease the CPI transcript level. This result is interesting and it may have two explanations: 1) D-amino acids of the growth media are possibly transferred to the plant cells and directly inhibit the activity of proteinase enzyme, or D-amino acids are firstly metabolized and then their metabolites exhibit the inhibitory activity towards proteinase; 2) D-amino acids or their metabolites are able to increase the inhibitory activity of the CPI molecule and therefore indirectly affect the proteinase activity. Since, the expression levels of CPI were detected to be very low as compared to $\mathrm{CP}$, therefore both the possibilities are predicted and need for more clarifications.

Among the test D-amino acids, D-serine was found to have more differential and considerable effects on $\mathrm{CP} / \mathrm{CPI}$ gene expressions. It not only does not increase the expression level of $\mathrm{CP}$ transcript but also completely inhibit the expression of CPI gene. This result may suggest the importance of Dserine and its possible regulatory roles as compared to other test D-amino acids in plant system.

Although, plants have been found to take up different $\mathrm{D}$-amino acids from their root system, but how plants are able to metabolize these compounds still remains as a puzzle. However, studies reported the presence of different metabolic pathways for D- 
amino acids in plant system [30]. On this base, our results may suggest the possible roles of $\mathrm{D}$-amino acids or their natural metabolites in CP/CPI activity that can be comparable to the roles of the synthetic or non-natural derivatives of $\mathrm{D}$-amino acids.

Conclusion. The potential effects of D-amino acids or their natural metabolites on the activity of proteolytic CP/CPI were predicted. However, this prediction is recommended to be investigated in details and compared to the already approved roles of non-natural compounds of D-amino acids with regard to the proteolytic system in plants.

The present work was financially supported by Research Institute for Fundamental Sciences (RIFS), University of Tabriz, Iran. The authors of this paper are thanks for their supporting.

\section{ВОЗМОЖНОЕ УЧАСТИЕ}

D-АМИНОКИСЛОТ ИЛИ ИХ МЕТАБОЛИТОВ

В ЦИСТЕИНПРОТЕИНАЗА/ЦИСТАТИНЗАВИСИМОМ ПРОТЕОЛИТИЧЕСКОМ ПУТИ У АРАБИДОПСИСА

\section{A. Gholizadeh}

Research Institute for Fundamental Sciences (RIFS), University of Tabriz, Iran

E-mail: aghz_bioch@yahoo.co.in

Цистеинпротеиназы и их ингибиторы цистатины играют существенную роль в росте и развитии растений. Они вовлечены в различные сигнальные пути и в ответ на широкий спектр биотических и абиотических стрессов. Для изучения возможного влияния на них D-аминокислот или их метаболизма in vivo проростки Arabidopsis выращивали на средах в присутствии четырех физико-химически различных аминокислот, включая D-аспартат, D-серин, D-аланин и D-фенилаланин. RT-PCR анализ цистеинпротеиназы и экспрессии гена цистатина показал, что добавление D-аминокислот в среду для выращивания растений значительно индуцировало экспрессию транскриптов протеиназ, в то же время снижая уровень экспрессии гена-ингибитора в тканях листьев и корней исследуемых растений. На основании полученных результатов обсуждается потенциальное влияние D-аминокислот или их метаболизма на активность в цистеинпротеиназа/цистатин-зависимом протеолитическом пути, а также их возможное взаимодействие в растительной системе.

\section{REFERENCES}

1. Wisniewski K., Zagdanska B. Genotype-dependent proteolytic response of spring wheat to water deficiency // J. Exp. Bot. - 2001. - 52. - P. 1455-1463.
2. Grudkowska M.M., Zagdańska B. Multifunctional role of plant cysteine proteinases // Acta Biochim. Polon. 2004. - 51. - P. 609-624.

3. Aberlenc-Bertossi F., Chabrillange N., Duval Y., Tregear J. Contrasting globulin and cysteine proteinase gene expression patterns reveal fundamental developmental differences between zygotic and somatic embryos of oil palm // Tree Physiol. - 2008. - 28. P. 1157-1167.

4. Fan J., Yang Y.W., Gao X. et al. Expression of a senescence-associated cysteine protease gene related to peel pitting of navel orange (Citrus sinensis L. Osbeck) // Plant Cell Tiss. Organ.Cult. - 2009. 98. - P. 281-289.

5. Rzychon M., Chmiel D., Stec-Niemczyk J. Modes of inhibition of cysteine proteases // Acta Biochim. Pol. - 2004. - 51. - P. 861-873.

6. Solomon M., Belenghi B., Delledonne M. et al. The involvement of cysteine proteases and protease inhibitor genes in the regulation of programmed cell death in plants // Plant Cell. - 1999. - 11. - P. 431443.

7. Martínez M., Cambra I., González-Melendi P. et al. C1A cysteine-proteases and their inhibitors in plants // Physiol. Plant. - 2012. - 145. - P. 85-94.

8. Bode W., Engh R., Musil D. et al. Mechanism of interaction of cysteine proteinases and their protein inhibitors as compared to the serine proteinase-inhibitor interaction // Biol. Chem. Hoppe-Seyler. 1990. - 371. - P. 111-118.

9. Grzonka Z., Jankowska E., Kasprzykowski F. et al. Structural studies of cysteine proteases and their inhibitors // Acta Biochim. Pol. - 2001. - 48. P. 1-20.

10. Santamaría M.E., Hernández-Crespo P., Ortego F. et al. Cysteine peptidases and their inhibitors in Tetranychus urticae: a comparative genomic approach // BMC Genom. - 2012. - 13. - P. 307-319.

11. Bode W., Huber $R$. Structural basis of the endoproteinase - protein inhibitor interaction // Biochim. Biophys. Acta. - 2000. - 1477. - P. 241-252.

12. Barrett A.J., Fritz H., Grubb A. Nomenclature and classification of the proteins homologous with the cysteine-proteinase inhibitor chicken cystatin // Biochem. J. - 1998. - 236. - P. 312-318.

13. Rawling N.D., Barrett A.J. Evolution of proteins of the cystatin superfamily // J. Mol. Evol. - 1990. 30. - P. 60-71.

14. Bateman A., Birney E., Cerruti L. et al. The Pfam protein families database // Nucl. Acids Res. - 2002. 30. - P. 276-280.

15. Martinez M., Diaz I. The origin and evolution of plant cystatins and their target cysteine proteinases indicate a complex functional relationship // BMC Evol. Biol. - 2008. - 8. - P. 198-209. 


\section{A. Gholizadeh}

16. Wiederanders B. Structure-function relationships in class CA1 cysteine peptidase propeptides // Acta Biochim. Pol. - 2003. - 50. - P. 691-713.

17. Simpson D.J. Proteolytic degradation of cereal prolamins - the problem with praline // Plant Sci. 2001. - 161. - P. 825-838.

18. Shindo T., Misas-Villamil J.C., Horger N.C. et al. A role in immunity for arabidopsis cysteine protease RD21, the ortholog of the tomato immune protease C14 // PLoS ONE. - 2012. - 7. - P. e29317.

19. Arai S., Matsumoto I., Emori Y., Abe K. Plant seed cystatins and their target enzymes of endogenous and exogenous origin // J. Agric. Food. Chem. - 2002. 50. - P. 6612-6617.

20. Diop N.N., Kidric M., Repellin A. et al. A multicystatin is induced by drought-stress in cowpea (Vigna unguiculata (L.) Walp.) leaves // FEBS Lett. - 2004. 577. - P. 545-550.

21. Belenghi B., Acconcia F., Trovato M. et al. AtCYS1, a cystatin from Arabidopsis thaliana, suppresses hypersensitive cell death // Eur. J. Biochem. - 2003. 270. - P. 2593-2604.

22. Tishkov V.L., Khoronenkova S.V. D-amino acid oxidase: structure, catalytic mechanism and practical application // Rus. J. Biochemistry. - 2005. - 70. P. 51-56.

23. Gholizadeh A., Faizi M.H., Kohnehrouz B.B. Molecular detection of drought stress-inducible D-amino acid oxidase gene from Zea mays L. // Asian J. Plant Sci. 2009. - 8. - P. 224-229.
24. Annedi S.C., Biabani F., Poduch E. et al. Engineering D-amino acid containing novel protease inhibitors using catalytic site architecture // Bioorg. Med. Chem. - 2006. - 14. - P. 214-236.

25. Sato A., Tri J., Nakahara K. et al. Combination of non-natural D-amino acid derivatives and allophenylnorstatine-dimethylthioproline scaffold in HIV protease inhibitors have high efficacy in mutant HIV // J. Med. Chem. - 2008. - 51. - P. 2992-3004.

26. Ausubel F.M., Brent R., Kingston R.E. et al. Current Protocols in Molecular Biology. - New York : John Wiley and Sons, 1991.

27. Livak K.J., Schmittgen T.D. Analysis of relative gene expression data using real-time quantitative PCR and the $2^{- \text {DDCt }}$ method // Methods. - 2001. - 25. P. 402-408.

28. Palma J.M., Sandalio L.M., Corpas F.J. et al. Plant proteases, protein degradation, and oxidative stress: role of peroxisomes // Plant Physiol. Biochem. 2002. - 40. - P. 521-530.

29. Ueda T., Seo S., Ohashi Y., Hashimoto J. Circadian and senescence-enhanced expression of a tobacco cysteine protease gene // Plant Mol. Biol. - 2000. 44. - P. 649-657.

30. Erickson O., Hertzberg M., Nasholm T. A conditional marker gene allowing both positive and negative selection in plants // Nat. Biotechnol. -2004. - 22. P. 455-458. 